\title{
O historiador, o santo, o feiticeiro e o tempo: notas sobre um diálogo “impróprio”
}

The history, the holy, the wizard and time: notes about an "improper" dialogue

\author{
Paulo Rogério Melo de Oliveira* \\ Universidade do Vale do Itajaí (UNIVALI), Itajaí, SC, Brasil
}

\begin{abstract}
RESUMO: Tomando como mote a rebelião indígena liderada pelo cacique/pajé Nezú, que resultou na morte do missionário Roque González, em 1628, na redução de Caaró, na Província Jesuítica do Uruguai, no atual noroeste do Rio Grande do Sul, o artigo traz algumas reflexóes sobre o tempo, sobre as relaçóes entre passado, presente e futuro, e propóe alguns questionamentos sobre as estratégias dos historiadores de retorno ao passado. Ocupamo-nos, também, sob o mesmo mote, da dimensão ética do trabalho do historiador e do cuidado em relação ao outro do passado.
\end{abstract}

PALAVRAS-CHAVE: Nezú. Roque González. Tempo. Passado. Presente.

ABSTRACT: The article brings some thoughts about time, relations between past, present, and future, and proposes some questions about the historians'strategies to return to the past, taking as a motto an indigenous rebellion led by cacique/pajé Ñezú, which resulted in the death of the missionary Roque González, in 1628, in Caaró's reduction of the Jesuit Province of Uruguay, current northeast of Rio Grande do Sul. Moreover, we deal, under the same motto, with the historian's work ethical dimension and the care toward the other from the past.

KEYWoRdS: Ñezú. Roque González. Time. Past. Present.

\footnotetext{
* Professor da Universidade do Vale do Itajaí (UNIVALI). Doutor em História pela Universidade Federal do Rio Grande do Sul (UFRGS). E-mail: paulo_rmo@hotmail.com. https://orcid.org/0000-0003-0311-8349.
} 
Como decifrar pictogramas de bá dez mil anos se nem sei decifrar minha escrita interior? Interrogo signos dúbios e suas variaçôes caleidoscópicas a cada segundo de observação

A verdade essencial é o desconbecido que me habita e a cada amanhecer me dá um soco.

Por ele sou também observado com ironia, desprezo, incompreensão $E$ assim vivemos, se ao confronto se chama viver, unidos, impossibilitados de desligamento, acomodados, adversos, roidos de infernal curiosidade. Carlos Drummond de Andrade - Corpo, novos poemas.

\section{Introdução}

Nas minhas pesquisas e nos meus escritos sobre a América espanhola do século XVII, desenvolvidos entre 2002 e 2012, mais especificamente sobre a morte do padre jesuíta Roque González de Santa Cruz e seus companheiros Juan del Castillo e Alonso Rodriguez, em novembro de 1628 , levada a cabo por emissários do cacique/pajé Nezú ${ }^{1}$, perguntava-me sobre o que de fato era possível apreender daquele passado remoto, esquecido e tão radicalmente diferente do tempo e do mundo em que vivemos. Era possível uma aproximação, a fim de traçar um perfil satisfatório daqueles personagens, para explicar a morte do padre Roque, as razóes de Nezú e as circunstâncias que os envolviam, sem incorrer em idealizações e juízos apriorísticos, sem projetar sobre eles as cargas, as urgências e os pressupostos que agiam sobre mim? Era possível dizer alguma coisa sobre aqueles homens sem fazer deles o que eles não eram? As trajetórias e as ações de Roque e Ñezú foram idealizadas, respectivamente, pela historiografia jesuítica e por boa parte da historiografia dedicada à resistência indígena na América colonial. Os dois personagens foram construídos com base nas expectativas da Companhia de Jesus e nas injunções de determinadas abordagens das ciências humanas. Roque morreu como "mártir" e seus pares reivindicaram o reconhecimento de sua santidade. Historiadores jesuítas e simpatizantes projetaram para o passado os episódios finais de sua vida. O martírio e a santidade foram os fios com base nos quais foram construídos os sentidos do passado. Quase tudo que se escreveu sobre ele foi com o propósito de confirmar a predestinação. Os hagiógrafos buscaram na infância, na juventude e nos trabalhos apostólicos os sinais inequívocos da santidade. A rebelião de Nezú contra os missionários foi vista pelos jesuítas, e pela historiografia jesuítica, como uma conjuração de inspiração satânica. Essa caracterização, 
por oposição, reforçava os apelos à canonização de Roque, morto por odium fidei, e entronizava mais um herói da fé na vasta lista dos mártires da Companhia de Jesus. A historiografia sobre os movimentos indígenas coloniais, na outra ponta, atribuiu à rebelião liderada pelo pajé um caráter messiânico, de resistência ao colonialismo, característico das abordagens histórico-sociológicas das décadas de 1970 e 1980, enxergando nela um conjunto de significados inexistente na documentação (OLIVEIRA, 2015a; 2015b). Procurei afastar-me destas abordagens e me ater aos documentos produzidos imediatamente após a morte do padre Roque, para manter-me o mais próximo possível dos acontecimentos que pretendia compreender.

Esses questionamentos sobre o conhecimento histórico, de fundo epistemológico, sobre o que é possível conhecer do passado, também dizem respeito ao cuidado com o outro que já não está mais entre nós, à dimensão ética do trabalho do historiador. Refletindo sobre a fragilidade epistemológica da história, Keith Jenkins observou que "[...] se é complicado ter conhecimento de algo que existe, então fica especialmente difícil dizer alguma coisa sobre um tema efetivamente ausente com é o passado na história” (2001, p. 30, p. 31). Drummond (1987) diria isso de outra maneira: "Como decifrar pictogramas de há dez mil anos se nem sei decifrar minha escrita interior?” (1987, p. 29-30).

Com base nestas indagações, o artigo propõe uma reflexão sobre as relações entre as instâncias de temporalidade - passado, presente e futuro -, e os caminhos que levam o historiador ao passado. Utilizo os personagens Nezú e Roque González como pontes para o passado, para pensar o "diálogo" que o historiador estabelece entre os tempos. A imagem da ponte evoca aqui uma forma de diálogo/passagem entre o presente e o passado. Como símbolo da associação, nas palavras de Simmel (1996), a ponte traça um caminho entre dois lugares, entre duas culturas. Tomo esta ideia de empréstimo para lançar uma ponte entre os tempos. Se a História é um diálogo dos sentidos do presente com os do passado, a metáfora da ponte pode orientar esse diálogo.

Por que esses personagens? Por que não figuras mais conhecidas, como os padre Romero e Boroa, e os caciques/pajés Oberá ou Zaguacari, mais presentes nas narrativas históricas? Porque Roque e Nezú, além de terem sido figuras características daquele tempo e espaço - um missionário e um chefe indígena -, foram personagens singulares, trágicos, que exprimem as tensões e os dilemas daquela sociedade. Roque era um missionário criollo invulgar, nascido em Assunção, em 1576, que dominava as línguas indígenas e desenvolveu métodos próprios de evangelização. Nezú era um feiticeiro ${ }^{2}$ de grande eloquência, que concentrava poderes políticos e religiosos e os exercia sobre outras lideranças indígenas da região. Sentindo-se ameaçado pela presença dos missionários, armou uma trama para livrar-se dos padres, visando a extirpar o cristianismo dos seus domínios, depois de ter concordado em erigir os fundamentos de uma redução (OLIVEIRA, 2010). A posteridade, ou o tempo que estava por vir, seria generoso com um e esqueceria-se do outro. Roque trilharia os caminhos da santidade. Nezú se tornaria, especialmente nas crônicas e historiografia jesuíticas, o feiticeiro diabólico e traiçoeiro que matou quem vinha para lhe salvar a alma. Debruçar-se sobre esses personagens, sobre os sentidos de suas açóes no passado e sobre as imagens que deles encontramos no presente, exige uma reflexão sobre o tempo e sobre os valores e conceitos que projetamos sobre o passado. Toda concepção de história, lembra-nos Agamben (2005, p. 111), "[...] é sempre acompanhada de uma certa experiência do tempo que lhe é implícita, que a condiciona e que é preciso, portanto, trazer à luz”. 
Pensar sobre o tempo é tarefa do historiador. Mas, não é uma tarefa exclusiva e tampouco solitária (HARTOG, 2003). As elaborações filosóficas e as apreensões que o tempo outrora despertou, desde Aristóteles e santo Agostinho, são-nos valiosas. Pensar o tempo é, de certo modo, uma forma de domesticá-lo, de construirmos com ele uma relação menos fatalista. Trata-se, portanto, de pensar o tempo não como um dado da natureza, o dito tempo natural, nem como um continuum linear, pontual e homogêneo que embalou as filosofias modernas do progresso, mas como construção histórica e cultural. Seguimos, então, na trilha daqueles que, em diferentes momentos, debruçaram-se sobre o tema e o tornaram um pouco menos nebuloso. As meditaçóes de Santo Agostinho e as reflexões de Heidegger sobre o tempo são as guias da nossa incursão pelos amplos e sinuosos domínios de Cronos. Do lado da história, as teorizações de Reinhart Koselleck e François Hartog oferecem-nos formulações mais contemporâneas, ligadas às nossas experiências com o tempo, cotidianas e intelectuais.

Os versos de Drummond podem ser lidos como moderadores de minhas pretensões em relação ao conhecimento histórico quando me dirijo ao passado, este outro desconhecido e intempestivo que habita uma dimensão mnemônica do presente.

\section{Os acontecimentos do passado}

Quinze de novembro de 1628. Padre Roque González de Santa Cruz havia fundado a redução de Caaró há quinze dias. Como de costume, nesta tomada simbólica do território que é a fundação de uma redução, ergueu uma cruz e batizou três crianças. Caaró nasceu da soma dos esforços e vontades dos caciques do Ijuí e do padre Roque, que desde fevereiro de 1627 estava na função de superior do Uruguai ${ }^{3}$. No dia quinze, padre Roque escreveu um bilhete ao padre Romero, que estava à frente da redução de Candelária, a uns dezessete quilôlmetros de Caaró, informando sobre o bom andamento dos trabalhos e lamentando não possuir mais cunhas de ferro, com as quais poderia atrair e reduzir mais quinhentos índios ${ }^{4}$. Depois de enviar o bilhete, foi rezar missa. Após a celebração, pôs-se a erguer um mastro no qual seria pendurado o sino. Enquanto preparava o campanário improvisado, auxiliado por um índio paraná que fazia os furos na madeira, um grupo de índios liderados pelo cacique Caarupé aproximou-se sorrateiramente. Sob ordens do cacique, um índio conhecido como Maranguá, aproveitando a posição encurvada do padre, que atava uma corda ao badalo do sino, desferiu-lhe dois pesados golpes de itaiça (machadinha de pedra) contra a cabeça. Roque González caiu morto. Alonso Rodriguez, que dizia missa perto dali, ouviu o ruído e saiu em direção ao tumulto. No caminho, foi abordado pelo grupo de Caarupé e teve o mesmo fim. Os corpos dos padres foram despidos, arrastados por um bom trecho, jogados dentro da igreja e queimados. Caarupé e o seu grupo, se confiarmos nas descriçóes dos companheiros do padre Roque, não agiram por iniciativa própria. Por trás do ato radical estava o feiticeiro Ñezú, o principal daquelas terras, um líder de grande fama e poder oratório, que vivia na região do Pirapó, nas proximidades do rio Ijuí, na margem oriental do rio Uruguai, atual Rio Grande do Sul. Enquanto seus emissários agiam, Nezú aguardava o desfecho dos acontecimentos no Pirapó. Assim que soube do sucesso da missão, festejou “[...] dando grandes patadas y gritos [...]”, e dirigiu-se com seu grupo para a redução de Assunção do Ijuí, na qual se encontrava o padre Juan del Castillo, para dar- lhe o mesmo fim (BLANCO, 1929, p. 471). Segundo padre Romero, que escapou por pouco 
dos emissários de Ñezú, os planos do feiticeiro eram bem mais ambiciosos: "[...] extirpar el santo Evangelio de todas estas provincias haciendo matar si pudiese todos sus predicadore" (BLANCO, 1929 , p. 469). Com pequenas variações, é isso o que nos informam as narrativas jesuíticas 5 sobre a trama urdida por Ñezú, que resultou na morte de Roque González .

Embora conheçamos em detalhes este episódio dramático da evangelização no Uruguai, a distância temporal e cultural que nos separa desses sujeitos e desses acontecimentos é enorme e, em certos aspectos, intransponível. Superar essa diferença irredutível é como tentar decifrar pictogramas “de há dez mil anos”. O que nos resta, para ensaiarmos uma aproximação, são algumas cartas/relatórios, escritas pelos companheiros de Roque González sobre as mortes, baseadas em depoimentos de indígenas que presenciaram os acontecimentos, e uma volumosa literatura jesuítica escrita desde o século XVII. Juntando com as cartas anuas referentes às Províncias do Paraguai e Uruguai, a memória jesuítica preservou um vasto material institucional sobre aqueles tempos, espalhado por inúmeros arquivos europeus e latino-americanos e publicado ao longo dos séculos XIX e XX em diversas obras arquivísticas. Os depoimentos indígenas merecem um pouco mais de atenção. Representam a voz do outro na vasta documentação jesuítica. Logo depois das mortes dos padres, alguns indígenas que presenciaram os acontecimentos foram interrogados por jesuítas e autoridades espanholas. As informações extraídas nos interrogatórios abasteceram os relatórios, escritos pelos padres que coordenavam os trabalhos missionários, enviados aos seus superiores na Europa. Nesses relatórios, as narrativas orais indígenas, mediadas pelas perguntas dos padres Romero e Clavijo, sobre as "causas" que levaram o cacique/feiticeiro a matar os padres, foram organizadas num texto escrito de caráter oficial. As informaçôes recolhidas dos indígenas foram absorvidas pelos padres e devolvidas noutro registro, como parte de uma narrativa maior na qual Nezú representava a encarnação do mal.

Os depoimentos dos indígenas são as fontes mais próximas para entendermos as razões de Nezú. Embora controladas pelos padres e condicionadas às perguntas do processo, são as únicas falas indígenas sobre o acontecimento. A historiografia em geral, jesuítica ou não, não faz menção a esses depoimentos. As raras vezes que são mencionados, como nos casos dos historiadores jesuítas Blanco e Teschauer, são para confirmar o ponto de vista jesuítico. As informações não variam muito dos depoimentos para as cartas. Os padres elaboraram seus relatos, em grande medida, com base nas falas indígenas. Mas existe uma diferença de fundo que deve ser observada. Nos depoimentos indígenas, não existem juízos de valor sobre Nezú. Os índios limitaram-se a responder o que lhes foi perguntado. Nas cartas, estas mesmas falas são cercadas de adjetivos e envolvidas por uma retórica jesuítica demonológica (OLIVEIRA, 2011).

A documentação, no seu conjunto, produzida no século XVII e nos séculos seguintes, é, sem dúvida, abundante, mas não nos abre mais do que uma pequena fresta para o passado. O domínio da escrita jesuítica sobre os acontecimentos de quinze de novembro de 1628 e a orientação de tudo o que foi escrito visando à canonização do padre Roque dificultam o trabalho do historiador que procura entender a relação entre o feiticeiro e o padre e interpretar as motivações da rebelião que culminou na morte dos missionários. Porém, sem estes registros escritos, não teríamos outra forma de acesso àquele passado. A fresta é estreita, a distância temporal e cultural é enorme, contudo é disso que dispomos. E os caminhos que nos levam ao passado, combinados com a leitura criativa dos documentos, para ler neles a voz do outro, ensinam-nos a arte de transformar frestas em janelas. 


\section{O historiador e o tempo: diálogos entre o presente e o passado}

Os registros escritos de outras épocas, convertidos em fontes para a história, são os guias de uma viagem metafórica do historiador no tempo. Por meio deles, deslocamo-nos a vários momentos do passado sem nunca abandonarmos o nosso tempo. Quando "mergulha no passado", para além de suas experiências e recordações, embalado pelas perguntas, pelas expectativas e inquietações que o mobilizam, o historiador depara-se com os vestígios de outros tempos. Transformados em fontes, esses vestígios passam a dar "[...] testemunhos da história que deseja apreender" (KOSELLECK, 2006, p. 305). Para Reinhart Koselleck, cada presente reconstrói o passado com base nas demandas que o singularizam. Mas, cada presente também ressignifica tanto o passado (visto como "campo da experiência”) quanto o futuro (“horizonte da expectativa”) e estabelece entre os tempos diferentes formas de relacionamento. Essa é uma das mais importantes contribuiçôes de Koselleck para pensar as instâncias do tempo: a percepção de uma tensão que se estabelece entre o "espaço de experiência" e o "horizonte de expectativas”, tensão que é própria da elaboração do conhecimento historiográfico e mesmo das múltiplas leituras sobre o fenômeno da temporalidade que vão surgindo em cada época.

Ao deslocar-se no tempo, "[...] o historiador sempre se movimenta em dois planos”. $\mathrm{O}$ primeiro movimento é uma aproximação do passado por meio da linguagem das fontes que nos abre o acesso heurístico àquela realidade. O segundo é uma aproximação conceitual por meio das categorias científicas do presente que o historiador transporta para o passado. Categorias construídas posteriormente, que são "[...] empregadas sem que sua existência nas fontes possa ser provada" (KOSELLECK, 2006, p. 306). Ciente destes dois planos, heurístico e conceitual, e dos limites que eles nos impóem, tentamos uma aproximação do distante mundo de Roque e Ñezú. É na trilha intratemporal dos registros escritos dos jesuítas, os vestígios do passado transformados em fontes, que recuamos no tempo perseguindo as pistas destes sujeitos, em busca dos significados daqueles acontecimentos. Esta viagem segue um roteiro que inclui um ponto de partida no presente: o turismo histórico e religioso organizado na região noroeste do Rio Grande do Sul, em torno do passado jesuítico e da figura do santo Roque González. Viajo com frequência para a região, a estudos ou a passeio, desde a década de 1980, e observo a utilização do passado missioneiro para impulsionar o turismo local. O santuário em homenagem ao santo Roque, a romaria de quinze de novembro e todo o complexo de ruínas dos Sete Povos, declarado patrimônio da humanidade pela UNESCO em 1983, conferiram uma identidade missioneira à região, que hoje em dia também conta com a Trilha dos Santos Mártires e o Caminho das Missões, caminhadas pelas antigas estradas usadas pelos jesuítas, oferecidas como atrativos extras para os visitantes. A figura dominante do santo Roque mobiliza e impulsiona economicamente toda a região, procurada por devotos e turistas de várias partes do Brasil e dos países vizinhos (Argentina, Paraguai e Uruguai). Mas, nos últimos anos, verificamos um esforço de escritores e historiadores locais no sentido de retirar a figura de Ñezú do esquecimento e integrá-lo com alguma dignidade à história regional, como parte do passado que também merece ser lembrado. Por vezes, deparamo-nos com situações curiosas, como é o caso do jornalista Nelson Hoffmann, que publicou em 2006 um livro intitulado Terra de Nheçu. Hoffmann, que é admirador incondicional e devoto do santo Roque, apresenta o feiticeiro como um bravo que levantou a voz contra o "branco invasor”. Apesar do título, e de uma passagem ou outra sobre o feiticeiro, o livro é sobre Roque González. Nheçu, ou melhor, a Terra de Nheçu, é apenas uma vaga denominação do lugar onde o mártir derramou seu sangue (OLIVEIRA, 2010). 
Esta é a fresta por onde observo e retorno ao passado, cujo ponto de referência é o dia quinze de novembro de 1628, e retorno de novo ao presente seguindo as trajetórias póstumas de Roque González e Nezú. Isto implica, ainda que modestamente, pensar o tempo. Mais precisamente, pensar as formas como passado, presente e futuro articulam-se na minha narrativa histórica.

As mudanças que, a partir do marco simbólico de 1989, abalaram as noções de tempo, que até então orientavam o trabalho de boa parte dos historiadores, impuseram uma redefinição do conceito de tempo e das relaçóes entre presente, passado e futuro. Um dos historiadores mais atentos a estas mudanças é François Hartog, que tem nos oferecido importantes reflexões sobre o tempo. Forjou uma expressão, "regime de historicidade", para expressar a maneira como uma sociedade "trata o seu passado" ou a "modalidade de consciência de si de uma comunidade humana". Hartog toma o ano de 1989 como ponto de partida de uma significativa ruptura com as concepções de tempo vigentes até então. Desde então, o Ocidente vive um novo "regime de historicidade" centrado no presente (HARTOG, 2006, p. 263). Até o final da década de 1980, as visões sobre o futuro e sobre a marcha da humanidade para a realização de uma finalidade histórica determinavam as leituras sobre o passado. A escrita da história, sob o magnetismo do futuro, reunia passado, presente e futuro num fluxo temporal contínuo que corria numa única direção. O passado era lido e organizado à luz de um futuro, por assim dizer, já conhecido. Buscavam-se no passado as evidências e as garantias da realização das promessas do amanhã. O presente era uma espécie de tempo-ponte, tempo de passagem entre dois registros temporais, entre o que foi e o que estava por vir.

As mudanças que abalaram o mundo turvaram e desacreditaram o futuro, provocando uma ruptura entre passado e futuro. A história, sob efeito dessas mudanças, deixou de ser escrita sob as expectativas e exigências do que estaria por vir. Desde então uma pergunta tornou-se frequente entre os historiadores: qual o significado do passado se o farol do futuro apagou? O estatuto do passado como etapa necessária de uma teleologia ruiu quando o muro de Berlim, imagem símbolo de uma época, veio abaixo. Passou a ser visto não mais como o lugar onde se encontrariam as evidências que confirmariam as previsões escatológicas. Tornou-se, então, um lugar opaco, difuso, tão incerto quanto o novo futuro, mas, por outro lado, aberto a novas interrogaçóes. Sem a previsibilidade imputada pelas certezas do futuro, o passado deixou de ser o lugar do óbvio e despontou como novidade, como um tempo a ser descoberto e percorrido sem que se saiba, de antemão, o que vai ser encontrado.

A ruptura da linha de comunicação entre o passado e o futuro teve um efeito correlato e não menos importante sobre as nossas formas de percepção do presente. Dos escombros do futuro, e desvencilhado do fardo do passado, ergueu-se um presente pleno. Se antes o presente, relegado a um mero tempo de passagem, comprimia-se entre um passado exemplar e um futuro radiante, nas duas últimas décadas, ele se expandiu e tornou-se próprio. Deixou de ser o depositário do passado e adquiriu sua própria identidade. Esta “ênfase crescente no presente enquanto tal” teve como efeito mais evidente uma valorização e um alargamento do presente (HARTOG, 1996, p. 10). A afirmação, hoje em dia, de uma história do tempo presente é um sintoma inequívoco desta valorização. É o reconhecimento de que o presente não é nem o passado recente nem o futuro próximo. É um tempo distinto, singular, com seus próprios movimentos, ritmos e demandas, que exige uma reflexão própria e noções metodológicas específicas.

A escrita da história, como não poderia deixar de ser, também sofreu os influxos dessa ênfase depositada no presente, que foi assumido também como condição da produção do conhecimento histórico. O tempo presente é o tempo do historiador que reconhece suas estratégias e os elementos 
subjetivistas de suas narrativas. Proposição típica dessa reorientação temporal é a ideia de que o passado é uma invenção do presente ${ }^{8}$. O eixo do tempo que orienta o olhar sobre o passado sofreu decisivo deslocamento. Teríamos saído de uma determinação do futuro para uma determinação do presente sobre a escrita da história?

Essas transformações na percepção do tempo e dos sentidos do passado, do presente e do futuro, exigem que explicitemos os nossos procedimentos e os caminhos de retorno ao passado. À volta ao passado, neste caso, a América do Sul do século XVII, não é um acontecimento místico, nem se realiza por passe de mágica. É uma operação técnica guiada por escolhas teóricas e metodológicas do presente. A expressão "volta ao passado" é, na verdade, um exercício de imaginação poética para compensar o drama epistemológico do historiador: a distância insuperável que nos separa do nosso objeto de investigação. O passado passou, não tem volta. Escrever sobre o passado, sobre pessoas que viveram no passado, é um gesto unidimensional em direção ao que já não existe mais. Mas, não é um movimento em direção ao vazio, ao nada. O passado não está morto. Ele está e não está lá. Mesmo não existindo mais, pode ser sentido, lembrado, visto e, em alguns casos, tocado. Os vestígios do passado, de um mundo que não existe mais, invadem o presente e projetam-se num tempo que lhes é estranho. Este passado residual tem uma existência paradoxal no presente. As ruínas de São Miguel das Missóes, observadas à maneira de Heidegger, são um gigante solitário e melancólico preso a um lugar que não é mais o seu. A cidade que cresceu à sua volta, com outros ritmos, com outras vozes, com sentidos, construções e ruídos diferentes, e que sobrevive em parte da exploração do passado do qual elas são as guardiãs, lhe é estranha. Silenciosas e majestosas, elas carregam as marcas de um tempo que já não é. As ruínas, fragmentos do passado que alcançaram o presente, são relíquias intratemporais que escaparam à fúria devoradora de Cronos. Situam-se numa região intersticial do tempo. São elos entre o que foi e o que é. Por isso, são mediadoras da historicidade, nossas pontes de acesso a um mundo que não é mais (HEIDEGGER, 2004).

Escrever sobre o que já não existe mais é recriar o que um dia foi. É trazer de volta o que estava perdido para sempre. Mas, o que o historiador traz de volta não é aquilo que um dia foi. Porque aquilo que um dia foi não pode mais ser. A "ressurreição" do passado não é um acontecimento místico. É um truque literário e um gesto científico. Não o truque do mágico ou do ilusionista, mas o do escritor, que traduz e organiza as experiências do passado em uma narrativa escrita e é capaz de condensar vários séculos em um punhado de páginas. Escrever sobre o passado é, pois, um exercício poético e uma arbitrariedade científica.

A história, de acordo com a voz corrente, promove um diálogo entre os tempos. Antes de endossar este ponto de vista, é necessário precisar os termos desta relação. A ideia do diálogo é, por assim dizer, "imprópria”. O dito diálogo com o passado é uma conversa sem interlocutor, na qual nós fazemos as perguntas, definimos os temas e oferecemos as respostas. É aquela situação meditativa e interrogativa em que nos encontramos quando estamos diante das ruínas de São Miguel, a conversar com as pedras. Somos nós que estabelecemos as relações, fazemos as escolhas, os recortes e as conjecturas sobre vestígios pétreos e silenciosos. É uma prática unilateral, uma escolha arbitrária, uma decisão de um lado só. O passado não existe mais. E não há diálogo entre termos que não coexistem. Santo Agostinho meditou sobre o tempo, no famoso capítulo XI de suas Confissóes, e constatou memoravelmente a dificuldade de explicá-lo. Numa bela passagem, argumentou que "[...] só de maneira imprópria se fala de passado, presente e futuro": 
Agora está claro e evidente para mim que o futuro e o passado não existem, e que não é exato falar de três tempos - passado, presente e futuro. Seria talvez mais justo dizer que os tempos são três, isto é, o presente dos fatos passados, o presente dos fatos presentes, o presente dos fatos futuros. E estes três tempos estão na mente e não os vejo em outro lugar. O presente do passado é a memória. O presente do presente é a visão. O presente do futuro é a espera. Se me é permitido falar assim, direi que vejo e admito três tempos, e três tempos existem. Diga-se mesmo que há três tempos: passado, presente e futuro, conforme a expressão abusiva em uso. Admito que se diga assim. Não me importo, não me oponho nem critico tal uso, contanto que se entenda: o futuro não existe agora, nem o passado. Raramente se fala com exatidão. O mais das vezes falamos impropriamente, mas entende-se o que queremos dizer (SANTO AGOSTINHO, 1984, p. 323, grifos nossos).

A proposição de Agostinho, de que passado e futuro não existem como realidades, senão como memória e expectativa da realidade presente, tem, sob certo aspecto, uma notável semelhança com a relação que estabelecemos hoje em dia entre os tempos. O passado não existe mais e o futuro ainda não passa de uma expectativa. Os dois existem como extensões e expressões do tempo presente. A ideia do diálogo, nestes termos, é “imprópria”, "mas entende-se o que queremos dizer". Da perspectiva do historiador, a proposição agostiniana, que só admite a existência do presente, a relação entre os tempos é um exercício de imaginação desde o presente que, orientado pelas categorias teóricas, pelas motivações políticas e sociais e baseado nos vestígios de tempos idos, permite ao historiador retornar ao passado, reconstruí-lo e organizá-lo historicamente. O presente é por onde o tempo caminha, mentalmente, na direção do passado e do futuro.

Embora Agostinho não estivesse pensando propriamente nos historiadores, a meditação oferece-nos ricos insights para pensarmos as conexóes entre os tempos e, especialmente, no presente como o lugar de onde lançamos pontes para o passado. O passado não existe mais, senão na memória e nos vestígios (materiais e imateriais) que resistiram ao tempo e à ação humana. Depois da intervenção do historiador, o passado, ou o que dele pode ser apreendido, passa a ter outra existência, ou uma segunda vida no presente. Não exatamente o passado, mas "o presente dos fatos passados", diria Agostinho.

Nezú e Roque González, o feiticeiro e o santo, nossas pontes para o passado, são os personagens centrais desse diálogo "impróprio" que tento estabelecer com o passado. Roque González, o missionário jesuíta "martirizado", em 1628, em Caaró, durante conversão dos Guaranis, foi declarado santo em 1988, por João Paulo II. Santo Roque conquistou a imortalidade e goza eterna lembrança. Nezú, o feiticeiro guarani, foi amaldiçoado. O “maldito” Nezú, segundo adjetivo de um dos hagiógrafos do santo Roque, foi condenado ao esquecimento. A trajetória póstuma dos dois personagens torna tudo mais difícil. Roque conquistou a glória dos altares e, na região onde foi morto, na qual antes Ñezú reinava soberano, ergue-se um santuário em sua homenagem. Todos os anos o santuário de Caaró abriga uma numerosa romaria com devotos dos três países que percorreu nas suas andanças missionários, Paraguai, Argentina e Brasil. Se no passado Roque era um homem que se engajou na Companhia de Jesus e se tornou um habilidoso missionário que se lançou na árdua tarefa de evangelizar os povos indígenas, no presente, alcançou a santidade e, na visão dos devotos, intervém a favor dos necessitados operando milagres. Quando voltamos ao passado, estamos examinando vestígios da vida do homem que virou santo. E todas as narrativas sobre ele, escritas em tom hagiográfico pelos seus companheiros de fé, exaltam as virtudes e os sinais de santidade, manifestadas precocemente. De minha parte, a do historiador que no presente 
interpela a volumosa documentação, deixando de lado a glorificação e a exaltação das virtudes, o que encontrei foi um homem de grande fé, como muitos de sua época, que desde muito cedo se afastou das honrarias da sociedade colonial para dedicar-se à evangelização dos indígenas que viviam nas cercanias de Assunção. Era habilidoso no que fazia, comunicava-se com facilidade com os índios, mas demonstrava certa impaciência e indisposição no trato com os novatos, que o procuravam para aprender as línguas nativas locais, com as quais tinha familiaridade desde a infância. Este traço de personalidade repercutiu entre os superiores da Companhia, a ponto de Roque receber uma dura repreensão pelo padre Geral Mucio Vitelleschi (OLIVEIRA, 2015) ${ }^{9}$. As cartas que escreveu para os seus superiores, embora presas às regras de composição da Companhia, dão-nos uma boa ideia dos métodos de conversão que empregou e das estratégias de aproximação dos índios, das geografias que percorreu e dos desafios que enfrentou adentrando em territórios inóspitos, dominados por caciques e pajés nem sempre dispostos a receber missionários.

Nezú, ao contrário, entrou para a posteridade como o traiçoeiro e diabólico matador do virtuoso Roque Gonzáles. E o fez por inspiração satânica. Tudo o que sabemos sobre ele foi escrito por aqueles que o amaldiçoaram. A historiografia jesuítica o condenou a uma triste nota de rodapé numa longa narrativa sobre as virtudes heroicas e as glórias do santo Roque. A historiografia sobre as lutas indígenas nas Américas praticamente o ignorou ${ }^{10}$. Os poucos rastros do feiticeiro são encontrados em território alheio, e os rastros não são exatamente seus. $O$ chefe guarani é um espectro fugidio, quase inapreensível, um fantasma mal falado que vaga pela documentação jesuítica. Em certa medida, ele é uma construção do discurso jesuítico. $\mathrm{Na}$ trama das narrativas da evangelização, representa o inimigo a ser vencido, o vassalo do diabo que opõe dura resistência aos companheiros de Jesus. Roque González, embora singular entre os jesuítas, é um sujeito perfeitamente localizável e explicável. Ñezú não. O feiticeiro é escorregadio, desmente hipóteses, dribla conceitos e embaralha as interpretações. Como objeto de investigação, situa-se numa zona ainda obscura entre a história e a etnografia (OLIVEIRA, 2011).

O Nezú que me foi possível apreender da documentação jesuítica, ou dos registros por eles controlados, não foi nem o feiticeiro diabólico, que matou os padres por ódio à fé, nem o líder messiânico, que trazia promessas de redenção, pois na rebelião que liderou não havia anúncio de paraísos nem um chamado a migrar, elementos centrais nos ditos movimentos messiânicos. $\mathrm{O}$ feiticeiro reclamava um retorno aos antigos costumes, ao antigo modo de vida, condenado pelos padres, e ameaçava os seus ouvintes com pavorosos cataclismos que viriam como castigo aos que não obedecessem. A trama urdida por Ñezú mobilizou índios e caciques, partidários do principal do Ijuí, que viam nos padres uma ameaça ao seu modo de vida. Mais do que isso, é adivinhar nele e na rebelião que liderou sentidos e significados que lhes escapavam.

Roque e Ñezú me chegam pelas cartas jesuíticas. As cartas, como expressão de um poder e de uma vontade, imprimiram as linhas do que deveria ser lembrado no futuro. Estamos de volta ao tema da lembrança e do esquecimento. Do passado, determinadas expressóes de poder definem o que deve ser lembrado no futuro. Do presente, os historiadores, situados num certo ambiente de poder e saber, decide sobre o que vai ser lembrado do passado. É desta tensão cambiante entre expressões de poder e saber de épocas distintas que se configura a escrita da história. A relação com o passado, assim me parece, tem duas pontas. Numa das pontas, está o historiador. Dessa perspectiva, a do presente, a escrita da história é sempre o exercício de um poder. O poder de dizer o passado diante do outro que é só silêncio. E dizer o passado é retirá-lo do esquecimento, é reintegrá-lo à ordem da memória. O que é lembrado e o que é esquecido, nesta recriação política 
do passado, é uma escolha do historiador. Recriamos experiências de vida de pessoas do passado e as desnudamos aos olhos de escrutínio do presente. Estabelecemos conjecturas sobre suas vidas, açôes e relações que elas nem sonharam. Muitas das ideias que levanto soariam, certamente, muito estranhas às minhas personagens. Elas estavam envolvidas numa teia de acontecimentos e significados cujo alcance lhes escapava. Séculos depois, essa teia torna-se visível ao historiador em toda sua espessura, complexidade e conexões ${ }^{11}$.

Mas, não é exatamente isso o que se espera de um “diálogo" entre mundos diferentes? É esta troca entre as experiências do passado e sua reconstrução histórica no presente que nos permite confrontarmos nossas próprias experiências. Se falássemos a mesma língua e vivêssemos os mesmos valores, qual a razão de estudá-los? Se trocarmos signos de vida é pelo desejo de conhecimento do outro, e de nós mesmos. Aprender com o passado é auscultá-lo em toda a sua estranheza, e não o acomodar às nossas certezas. Confrontá-lo com o presente é ressaltar sua singularidade, e a nossa. É apreender a mudança, e aprender a conviver com ela.

Aprender com as experiências do passado exige de nós, antes de tudo, um profundo respeito em relação ao outro que, de todo modo, é ausente. Exige, igualmente, o cuidado ${ }^{12}$ para não fazermos dele um trampolim para as nossas ambições ou um ventríloquo das nossas crenças e preferências políticas. Respeito também às regras do ofício do historiador, especialmente no trato com as fontes, que impõem certos limites ao nosso exercício de imaginação histórica. Da pesquisa e busca de informações às interpretaçôes, os historiadores têm a responsabilidade de obedecer e respeitar às normas confiáveis do seu ofício, correspondam ou não suas conclusões aos seus desejos e expectativas (PORTELLI, 1997). Esta ética profissional, específica da nossa categoria e do nosso métier, é um desdobramento prático de um sentido mais amplo e anterior, que Paul Ricouer denominou de éticas fundamentais, como a Ética a Nicômaco ou a Ética de Spinoza. Não é minha intenção esmiuçar as complexas relações entre história e ética, esforço desnecessário para os propósitos deste artigo, mas apenas chamar a atenção para algumas questões que podem dar suporte para a relação que estabelecemos com o passado. Paul Ricouer, no Dicionário de ética e filosofia moral, divide a ética em dois ramos: "um ramo designando o que está a montante das normas - falarei então de ética anterior - e outro ramo designando o que está a jusante das normas - falarei então de ética posterior"; a ética anterior, "apontando para o enraizamento das normas na vida e no desejo", e a ética posterior "visando a inserir as normas em situações concretas". A moral é uma "estrutura de transição que guia a transferência da ética fundamental em direção a éticas aplicadas que lhe dão visibilidade e legibilidade no plano da práxis". Do conceito mais geral, ou "do sentido nobre do termo", Ricouer aponta para "[...] os dispositivos práticos que convidam a colocar a palavra 'ética' no plural e a acompanhar o termo de um complemento, como quando falamos de ética médica, de ética jurídica, de ética dos negócios etc” (RICOEUR, 2003, p. 591-595), e da ética dos historiadores, acrescentaríamos.

Trazendo as reflexóes de Ricouer para o nosso tempo, e para a turbulência política dos nossos dias, Benito Schmidt lançou importante provocação/proposição: Nesta nossa atualidade - marcada, simultaneamente, pela negação da igualdade e pelo desrespeito à diferença - talvez a mais fundamental intenção ética a informar as éticas particulares seja aquela que possa articular uma tríade em que o si, o outro próximo e o outro distante apareçam como igualmente honrados, o que Ricoeur resume na fórmula: 'viver bem, com e para os outros, dentro de instituiçôes justas'. Que possamos, como cidadãos e historiadores, transformá-la em norma de conduta e sabedoria prática” (2014, p. 20). 
Respeito e cuidado são as balizas éticas que orientam o nosso trabalho e os "diálogos", sempre provisórios, que propomos com os sujeitos do passado, ainda que suas vozes, lacunares e fugidias nos cheguem indiretamente. As representações que do passado construímos, além de admitir a possibilidade de outras interpretações e de múltiplas narrativas, nunca são definitivas. Esta percepção nos protege da tentação de nos tornarmos juízes do passado e senhores da verdade.

O presente para o historiador não é e não pode ser um tribunal que julga e demoniza nem um altar que santifica. Na mão oposta, em certa medida, o trabalho do historiador pode libertar o passado, e personagens como Nezú e padre Roque, dos anátemas e das idealizações que os transformaram em modelos de projetos políticos e religiosos a serem alcançados no presente. Apontar as projeções que sobre eles foram anacronicamente lançadas é uma forma de restituir-lhes a alteridade.

\section{Considerações finais}

Não temos como voltar no tempo e vivenciar/observar in loco as experiências do passado. Nossas formas de acesso aos tempos idos, sempre indiretas, são as memórias ou os vestígios que sobreviveram ao tempo e chegaram até nós. É esta a fragilidade epistemológica da história, diria Keith Jenkins, ou os limites que controlam as pretensóes dos historiadores (2001, p. 30). O historiador, especialista no trato com os vestígios do passado, é, em tese, quem melhor promove o "diálogo" entre os tempos, ainda que o "diálogo" seja "impróprio". Presente e passado encontram-se pela mão do historiador. Do lado de cá, fazemos nossas escolhas, mas o acesso que temos ao passado só nos é possível por meio daquilo que o lado de lá nos permitiu ler. O poder de transmitir ao futuro aquilo que será lembrado é o poder que o passado tem de impor uma imagem de si ao presente. Esta angulação nos permite relativizar a ideia de que o passado é simplesmente uma invenção do presente. Em certo sentido o é, mas esta invenção é limitada por aquilo que determinadas relações de força e poder de outras épocas autorizaram chegasse até o presente. $O$ presente inventa o passado até onde o passado o autoriza.

Escrevi uma longa tese sobre Roque González e Nezú. Interpretei-os como personagens trágicos de uma das mais extraordinárias experiências históricas: o encontro entre os guaranis e os jesuítas, na primeira metade do século XVII, nas regióes denominadas Paraguai e Uruguai. Caracterizei a rebelião de Nezú, com a ajuda da etnografia, como uma das melhores traduções das tensões e ambiguidades que presidiram o projeto colonial de conversão dos indígenas na América do Sul (OLIVEIRA, 2011). Em certo sentido, eu os (re)inventei. Projetei para o século XVII conceitos e noções do presente, completamente estranhos àquele tempo, “empregadas” diria Koselleck, “[...] sem que sua existência nas fontes possa ser provada” (2006, p. 306). Todavia, sem a mediação dos conceitos e das noções oferecidos por historiadores, etnólogos e filósofos contemporâneos, que nos auxiliam na leitura e interpretação das fontes coloniais, restaria reproduzir o conteúdo das cartas dos companheiros de fé de Roque González e subscrever uma visão idealizada do padre Roque e demonizada de Nezú. A virtuosa santidade de Roque e a personalidade diabólica de Nezú são invenções do imaginário jesuítico.

Por um lado, eu os (re)inventei procurando olhar para além dos filtros institucionais, europeus e demonológicos, que modulavam o discurso jesuítico, e para além da trama diabólica habilmente costurada pelos companheiros de fé de Roque, para justificar a canonização. O termo invenção que utilizo ao longo do artigo é, em grande medida, inspirado em Edmundo O'Gorman. Segundo o historiador mexicano, “a opção pelo termo invenção" é sugestiva pela ambiguidade que possibilita: 
de um lado, o termo vem acompanhado de toda uma visão da América, na qual predomina o fantástico, o fabuloso, o legendário, o mítico; de outro, o termo pode lembrar algo que é construído racionalmente (O'GORMAN, 1992, p. 12). O uso que faço do termo sugere que os arranjos teóricos e linguísticos dos historiadores empregados para reconstruir as experiências do passado resultam na criação de algo novo, que combina vestígios do passado com expectativas do presente, ou fragmentos e narrativas de vidas de outro tempo, das quais não podemos nos distanciar, com as exigências do nosso tempo, às quais devemos prestar contas, dar satisfações e respostas, por vezes, canônicas. A invenção dos historiadores decorre de uma negociação, ou de um diálogo "impróprio", entre as forças do passado com as do presente. Por outro lado, procurei manter-me atento aos registros escritos do século XVII, descartando categorias e conceitos - como messianismo e "terra sem mal”13 - que não correspondessem ao conteúdo da documentação disponível. Eu os (re)inventei respeitando os limites daquilo que do passado chegou até nós, daquilo que aquele passado me autorizava dizer.

\section{Referências}

ACOSTA, José de. Predicación del Evangelio en las Índias. Estudio preliminar y edición del P. Francisco Mateos. Madrid: Atlas, 1954.

AGAMBEN, Giorgio. Infância e história: destruição da experiência e origem da história. Belo Horizonte: Editora UFMG, 2005.

ANDRADE, Carlos Drummond. Corpo, novos poemas. Rio de Janeiro: Editora Record, 1987.

ARDANAZ, Dayse Ripodas. Pervivencia de hechiceros en las misiones guaranies. Folia Histórica del Nordeste. Resistencia, n. 6, 1984.

ARDANAZ, Dayse Ripodas. Movimientos Shamanicos de Liberación entre los Guaraníes (1545-1660). Teología, Buenos Aires. tomo XXIV, n. 50, 1987.

BLANCO, José Maria. História documentada de la vida y gloriosa muerte de los padres Roque González de Santa Cruz, Alonso Rodríguez y Juan Del Castillo de la Compañia de Jesús Mártires del Caaró e Yjuhí. Buenos Aires: Sebastián de Amorrortu, 1929.

BOSI, Alfredo. O tempo e os tempos. In: NOVAES, Adauto (org.). Tempo e história. São Paulo: Companhia das Letras, 1992.

GUIGNON, Charles (org.). The Cambridge Companion to Heidegger. Cambridge: Cambridge University Press, 1993.

HARTOG, François. Tempo e Patrimônio. Varia hist. v. 22, n. 36. Belo Horizonte. jul./dez. 2006.

HARTOG, François. Regime de historicidade. Time, History and the writing of History) - KVHAA Konferenser, v. 37. Stockholm, p. 95-113,1996. Disponivel em: http://www. fflch.usp.br/d h/hero s/excerp ta/harto g/hartog. html >. Acesso em: 14 nov. 2019.

HEIDEGGER, Martin. Ser e tempo. Parte I. Rio de Janeiro: Editora Vozes, 1986.

HEIDEGGER, Martin. Ser e tempo. Parte II. Rio de Janeiro: Editora Vozes, 2004.

JENKINS, Keith. A história repensada. São Paulo: Contexto, 2001.

JUNIOR, Durval Muniz de Albuquerque. História: a arte de inventar o passado. Bauru: Edusc, 2007.

KOSELLECK, Reinhart. Futuro Passado: contribuições à semântica dos tempos históricos. Rio de Janeiro: Contraponto: Editora PUC-Rio, 2006.

MELIĀ, Bartomeu. El guarani conquistado y reducido: ensayos de etnohistória. Asunción: Biblioteca Paraguaya de Antropologia, v. 5, 1988. 
MONTOYA, Antonio Ruiz de. Conquista Espiritual hecha por los religiosos de la Campañia de Jesus en las Províncias de Paraguay, Paraná, Uruguay y Tape. Rosário: Equipo Difusor de Historia Iberoamericana. Estúdio preliminar y notas Dr. Ernesto Maeder, 1989.

O־GORMAN, Edmundo. A invenção da América. São Paulo: Editora da UNESP, 1992.

OLIVEIRA, Paulo Rogério Melo de. “Terra sem mal” e messianismo entre os guarani do Paraguai colonial (séc. XVI e XVII). Interseções, Revista de Estudos Interdisciplinares. v. 17, n. 2, 2015 a.

OLIVEIRA, Paulo Rogério Melo de. Roque González: entre a história e a hagiografia. Revista Brasileira de História das Religiões. v. 8, n. 28, 2015b.

OLIVEIRA, Paulo Rogério Melo de. O encontro entre os guarani e os jesuítas na Província do Paraguai e o glorioso martírio do venerável padre Roque González nas tierras de Ñezú. Universidade Federal do Rio Grande do Sul. Instituto de Filosofia e Ciências Humanas. (Doutorado em História). Programa de Pós-Graduação em História, 2010.

OLIVEIRA, Paulo Rogério Melo de. A rebelião de Ñezú: em defesa de “su antiguo modo de vida” (Pirapó, Província Jesuítica do Paraguai, 1628). Anos 90 - Revista do Programa de Pós-Graduação em História da UFRGS, v 18, n. 34, 2011.

POMPA, Cristina. Religião como tradução. Bauru: EDUSC, 2003.

PORTELLI, Alessandro. Tentando aprender um pouquinho. Algumas reflexões sobre ética na História Oral. Projeto História, São Paulo, n. 15, abr. 1997.

RICOEUR, Paul. Ética. Da moral à ética e às éticas. In: Dicionário de ética e filosofia moral. São Leopoldo: Ed. UNISINOS, 2003. p. 591-595.

SANTO AGOSTINHO. Confissões. São Paulo: Edições Paulinas, 1984.

SCHMIDT, Benito Bisso. Quando o historiador espia pelo buraco da fechadura: biografia e ética. História. São Paulo. v. 33, n. 1, p. 124-144, jan./jun. 2014.

SIMMEL, Georg. A ponte e a porta. Política e Trabalho, v. 12, PrPGS. Universidade Federal da Paraíba. Tradução de Simone Maldonado, set. 1996.

TECHO, Nicolás Del. Historia de la Provincia del Paraguay de la Compañía de Jesús. In: Biblioteca Virtual del Paraguay. s/d.

\title{
Notas
}

\begin{abstract}
${ }^{1}$ Não exite acordo quanto à grafia do nome do chefe guarani. Em Montoya, aparece como Neçú, Techo e Charlevoix, apresentam-no como Niezú, e, em Teschauer, encontramos Nheçum. Padre José María Blanco (1928), numa longa obra dedicada à canonização de Roque González, uniformizou o nome e usou Ñezú em todas as citações e transcrições que fez dos documentos produzidos no ano de 1628 e no começo de 1629 referentes à rebelião indígena que culminou na morte dos missionários. Optei pela grafia Ñezú, conforme aparece em Blanco.
\end{abstract}

2 Os líderes espirituais guarani são identificados de várias maneiras. Nos documentos dos tempos coloniais aparecem como hechiceros e payés. Os etnólogos e etnohistoriadores empregam o termo xamã, que vem da palavra "saman", do povo tungu, da Sibéira. Optei por usar os termos hechicero/feiticeiro e pajé para permanecer mais próximo das fontes. Quando uso o termo feiticeiro, reconheço a projeção cultural europeia sobre os pajés.

${ }^{3}$ A redução de Caaró localizava-se na região então denominada Uruguay, situada à margem esquerda do rio Uruguai. Em fevereiro de 1627, o padre Provincial Mastrilli Duran nomeou Roque González superior do Uruguay.

${ }^{4}$ Os equívocos e as implicações do uso do conceito genérico de "índio" para descrever os povos habitantes das Américas são bastante conhecidos. Uso esse conceito ao longo do tex to com aquele mesmo cuidado que o padre Acosta recomendou ao tentar descrever aos seus leitores a diversidade dos povos e culturas do Novo Mundo. Embora todos tenham sido chamados de índios pelos descobridores, existem muitas diferenças entre esses povos, advertia Acosta (ACOSTA,1954).

${ }^{5}$ Uso a expressão narrativas jesuíticas para me referir, especificamente, as cartas/relatórios escritos pelos companheiros do padre Roque para explicar aos seus Superiores, na América e na Europa, os acontecimentos que vitimaram os missionários.

${ }^{6}$ As crônicas de Ruiz de Montoya e do padre Techo, escritas muitos anos depois das mortes dos padres, são normalmente as fontes mais conhecidas e usadas pelos historiadores que estudam este tema. Mas, são as cartas/relatórios enviadas 
a Roma pelos padres Pedro Romero, Diego Boroa, Vasquez Trujillo e Ferrufino e, principalmente, os testemunhos indígenas recolhidos logo após as mortes dos missionários, reunidos na obra do padre Blanco, infelizmente desconhecidos da maioria dos historiadores, que nos trazem informações mais detalhadas do acontecimento e dos personagens envolvidos (OLIVEIRA, 2011).

${ }^{7}$ Exploro infielmente aqui uma ideia de Koselleck sobre a transformação dos vestígios do passado em fontes para a história e como por meio deles nos dirigimos ao passado (KOSELLECK, 2006, p. 305).

${ }^{8}$ Entre outros importantes estudos, cito o livro $A$ arte de inventar o passado, de Durval Muniz de Albuquerque Junior. No capítulo que dá título ao livro, Durval argumenta que o conhecimento histórico é “[...] invenção de uma cultura particular, num determinado momento, que, embora se mantenha colado aos monumentos deixados pelo passado, à sua textualidade e à sua visibilidade, tem que lançar da imaginação para imprimir um novo significado a estes fragmentos" (JUNIOR, 2007, p. 63). Não discordo de Durval, pelo contrário, reforço o seu ponto de vista. Apenas, como mostro mais adiante, procuro pesar a participação do passado, por meio dos monumentos que deixou, na arte de sua invenção. Se o presente inventa o passado "imprimindo novos significados" aos fragmentos deixados, não seria um exercício oportuno, apenas para balancear as forças, imaginar o contrário? Deixo esse exercício para uma outra oportunidade.

${ }^{9}$ Da extensa documentação, alguns episódios da vida do padre Roque são muito valorizados, ao passo que outros são obliterados. As informações que podem depor contra a "fama de santidade", como a impaciência e certa grosseria que adotava com os novatos, são desabonadas. Seus hagiógrafos, especialmente os padres José María Blanco e Gonzaga Jaeger, saíram em sua defesa e declaram-se admirados com as cobranças do padre Geral. Reprovaram a passagem, a única em toda a documentação, dizem eles, e julgaram-na como um mal-entendido. Num artigo dedicado às hagiografias do padre Roque, trato do tema com mais detalhes (OLIVEIRA, 2015).

${ }^{10}$ Entre os pouquíssimos pesquisadores que se ocuparam deste tema, não considerando os jesuítas, destaco: Branislawa Susnik, Maria Cristina dos Santos, Bartomeu Melià, Dayse Ripodas Ardanaz e, mais recentemente, Guillermo Wilde.

${ }^{11}$ O léxico simplificador, como diria Alfredo Bosi, e os conceitos - colonizador, índio, pajé, jesuíta - que empregamos para descrever ou classificar homens e mulheres do passado, devoram, em parte, as suas subjetividades e intersubjetividades (BOSI, 1992).

${ }^{12}$ Refiro-me ao sentido heideggeriano de cuidado, que o define como expressão ontológica da nossa existência. Com base na narrativa extraída das fábulas Higino, Heidegger sugere que Cuidado, personagem mítico que criou os seres humanos, faz parte da constituição do ser (HEIDEGGER, 1986, p. 263-266). Numa disputa entre os deuses sobre a criatura recémcriada, Cronos, escolhido como árbitro, decidiu que depois de morto, o espírito do homo (humano) seria recebido por Zeus, enquanto o corpo ficaria na Terra. Cuidado foi encarregado por Cronos de reger a vida humana neste mundo. Enquanto vivermos estaremos sob o olhar atento de Cuidado. Deixando de lado os essencialismos, o mito é inspirador para pensarmos numa ética humana, no tempo em que nos cabe viver. Neste artigo, livremente inspirado em Heidegger, entendo o cuidado como uma categoria que implica uma ética que pode orientar os nossos diálogos com a alteridade, do presente e do passado, já que Cuidado, que zela pela humanidade, recebeu esta responsabilidade do deus que representa o tempo. Uma ética do cuidado, da maneira como estamos sugerindo, nos impõe a responsabilidade com o outro. A própria noção de historicidade em Heidegger aponta para o reconhecimento de que o nosso estar-no-mundo é tecido por relações de responsabilidade com outros seres humanos, e isso não é uma escolha arbitrária (GUIGNON, 1993). Pensando no ofício do historiador, a ética do cuidado se estende à alteridade do passado.

${ }^{13} \mathrm{~A}$ “terra sem mal" é um típico caso de projeção, neste caso, etnográfica, de um conceito do presente para o passado, que não encontra respaldo nas fontes. Cristina Pompa (2003), relendo a documentação colonial, levantou sérios questionamentos sobre a existência do paraíso tupi-guarani no que diz respeito à América portuguesa. No caso do Paraguai colonial, como procuramos demonstrar num estudo anterior (2015a), também não existe registros sobre a "terra sem mal" na documentação jesuítica nem nos relatos dos cronistas dos primeiros tempos da conquista. As descobertas etnográficas de Nimuendajú sobre a "terra sem mal" entre os guaranis, que contatou no início do século XX, foram aceitas e projetadas para os povos tupi e guarani contatados pelos europeus nos séculos XVI e XVII. A documentação colonial foi lida à luz da etnografia com vistas a comprovar a tese da persistência dos movimentos migratórios em busca do paraíso terrestre entre os guaranis, desde os tempos anteriores às conquistas europeias.

Recebido em: 08/01/2020

Aprovado em: 20/04/2020 